Dr Bela Bonita Chatterjee ${ }^{\text {a* }}$

${ }^{a}$ Centre for Crime, Law and Justice, School of Law, Lancaster University, Lancaster, UK

*b.chatterjee@lancaster.ac.uk 


\section{Child sex dolls and robots: challenging the boundaries of the child protection framework}

Foreign-made child sex dolls are now commercially available online, and recent cases indicate that their importation is a criminal offence. However, whilst there are growing calls for criminalisation, it is unclear as to where the law stands in relation to them and their robotic counterparts. This article seeks to initiate debate by asking; could and should child sex dolls and robots be caught by the child protection framework? Considering core offences, it explores whether and where such items might fit within the current law. The argument proposed is that that whilst there may be patchy coverage no single statute provides a convincing match. Drawing analogies to legal debates on child pornography, the article considers various justifications for criminalisation. Following a harm-based perspective, it proposes new crimes under the Sexual Offences Act 2003 ('SOA') which address the creation, distribution and possession of child sex dolls and robots where a real child is involved in their creation. Where sex dolls and robots are fantasy creations, it is argued that different considerations arise and it is difficult to justify the same range of restrictions. Accordingly, separate SOA offences are suggested with exception made for self-made artefacts that are intended solely for private use.

Keywords: child sex dolls; child sex robots; criminalisation

\section{Introduction}

Whilst sex dolls have been around for a long time, they are now very different to the traditional, basic stag-party inflatable (Horton 2015; Bodkin 2016; Palmer 2016; Cheok and Levy 2017; Levy 2009; Sharkey et al. 2016; Levy in Lin et al. 2012; Campaign against Sex Robots 2012; Richardson (forthcoming) 2019; Devlin 2018; Devlin 2015; Danaher and McArthur 2018; Sparrow 2017; Guitu in Calo, Froomkin and Kerr 2016). Due to developments in materials they can be increasingly realistic, particularly so when combined with electronic and robotic functions. They can be controlled by programming apps and made to possess sensory and tactile capacity, with lifelike mannerisms and facial expressions, as well as the ability to vocalise and understand language. ${ }^{1}$ Sex doll brothels are becoming increasingly popular worldwide (Day 2017; Nash 2017, 2018), and although a wholly roboticised i.e. completely articulated, life-sized and convincingly mobile version of a doll is not yet on the market, at the time of writing (2018-2019) 
developers are working on a prototype called Harmony, with a view to it being the world's first commercially available and fully functional adult sex robot. ${ }^{2}$ Yet while debates are starting to develop as to the legal, moral and ethical questions posed by adult sex dolls and robots (Horton 2015; Bodkin 2016; Palmer 2016; Cheok and Levy 2017; Levy 2009; Sharkey et al. 2016; Levy in Lin, Abney and Bekey 2012; Campaign against Sex Robots 2012; Richardson, forthcoming, 2019; Devlin 2018; Devlin 2015; Danaher and McArthur 2018; Sparrow 2017; Guitu in Calo, Froomkin and Kerr 2016), there is also a need to consider the issues raised by such items being created for those with a sexual interest in children, particularly because a market is now established and increasing (Rawlinson 2017). ${ }^{3}$ Oriental companies have been manufacturing and selling child sex dolls - that is to say, non-electronic/robotic but realistic three-dimensional representations of children - globally, for over a decade (see eg Sharkey et al. 2016), and such dolls are now starting to appear in the UK (McCrum 2016; Rawlinson 2017). It is only a matter of time before roboticised versions arrive.

From a legal perspective, the question of whether and how to regulate child sex dolls and robots is thus an increasingly pressing but largely unanswered one. Some clarity has recently been provided by $R v$ Dobson (2017, unreported; see Briefreport 2017). ${ }^{4}$ In this case, a man was successfully prosecuted at Chester Crown Court for importing a sex doll designed to resemble a child of between four and six years old (unreported, see Briefreport 2017). The doll, purchased via eBay and labelled simply as a 'mannequin', was discovered by Border Force officials at East Midlands Airport following its importation from Hong Kong (Briefreport 2017). The case was brought under the Customs Consolidation Act 1876 (hereinafter 'CCA'), whereby it is an offence under s.42 to import 'Indecent or obscene prints, paintings photographs, books, cards, lithographic or other engravings, or any other indecent or obscene articles. ${ }^{5}$ This example of importation is not an isolated incident. Commenting on the more recent case of $R v$ Turner (2017 unreported, see Rawlinson 2017), Border Force officials stated that 123 dolls had been intercepted in just over a year, with seven people charged with their importation (Rawlinson 2017; see also briefly Matthews 2019, 286). Of the seven charged, six faced allegations connected with child pornography (Rawlinson 2017). The defendant in Turner himself was reported to have pleaded guilty in an earlier hearing to possessing or creating more than 34,000 indecent images (Rawlinson 2017), whilst in a third case $(R v$ 
Charnock, 2018, unreported, see Lancashire Police 2018) the defendant was found to have some 6,000 indecent images. A fourth case $R v$ Doel (Cork 2018), was also due for hearing in 2018.

Increasing popular awareness of child sex dolls has led to calls for them and their robotic successors to be banned; a view countered by those who see them as potentially therapeutic or diversionary for child sex offenders (as debated in Sharkey et al 2016; Richardson 2015; Matthews 2019; Behrendt 2017; Strikwerda 2016; Dean 2016; Wakefield 2017; Morin 2016). As seen above, the importation cases clearly indicate that the domestic law considers child sex dolls (and presumably by extension robots) as a serious matter for criminal censure and specifically as a question of child protection: It is notable that Dobson received a higher sentence for the importation of the doll (immediate custodial sentence of 2 years) than his sentence for the three counts of making and possessing indecent images of children ( 8 months). ${ }^{6}$ However, existing cases deal with the question of importation only, and it is currently unclear as to where the law stands in relation to domestic offences. It is highly likely, particularly given the expansive trend in criminalising sexualised representations of children (Gillespie 2018), that child sex dolls and robots will also be prohibited, but how this might be done, to what extent, and whether it is even correct to do so, is uncertain. Reflecting how reprographic technology has developed, the current child protection framework focuses on two-dimensional material; chiefly photographs and particularly those online. It is therefore unclear as to whether, where and how three-dimensional material might fit in. At the time of writing there is no case law on how the law might respond to the domestic production, circulation and possession of child sex dolls, and likewise a lack of scholarly legal discussion on child sex robots as the next likely development in the field. ${ }^{7}$ Given the dearth of legal commentary and critique, this article seeks to catalyse the debate.

The analysis starts by considering the initial question of whether child sex dolls and robots could be covered by the existing domestic legal framework, touching on other three-dimensional images (holograms) where appropriate. Core offences of creation, dissemination and possession are considered, starting with the Protection of Children Act 1978, then moving to the Coroners and Justice Act 2009; the Sexual Offences Act 2003; Obscene Publications Acts 1959 and 1964, and other communications offences. I argue 
that none of these statutes as they stand are squarely appropriate, requiring highly strained interpretation or providing only limited cover.

Exploring whether child sex dolls and robots should be criminalised, I reference current academic legal debates on child pornography, with particular consideration given to discussions of purely fantasy imagery not based on a real child (particularly Al-Alosi 2018, also Strikwerda 2016; Ost 2010). ${ }^{8}$ Evaluating various positions, I argue that in order for the law to develop on the most coherent and defensible footing, it should follow a harm-based rationale whereby the criminalisation of child sex dolls and robots can be justified where a real child is involved in the process of their creation. To this end, I suggest that a specific offence could be created under the Sexual Offences Act 2003 which would criminalise the creation, distribution and possession of a simulated child made for sexual purposes when based on a real child. In considering whether even purely fantasy child sex dolls and robots should be restricted or prohibited outright, it is somewhat less easy to reach a conclusion and I note arguments on both sides. Considering cultural harm arguments, which hold that the non-consensual circulation of abusive material gives rise to collective harm by creating an atmosphere that normalises and legitimises such abuse, I apply this reasoning to abstract child sex dolls and robots, and suggest that the wider cultural harms argument may justify restriction in cases where they reach the public domain i.e. dissemination and creation/possession with intent to disseminate, but that where such objects are self-created for private use only, restriction would be an unjustifiable encroach on privacy and freedom of expression.

\section{The Protection of Children Act $\mathbf{1 9 7 8}$}

In considering whether and where child sex dolls and robots might fit into the current framework, the logical place to start is the Protection of Children Act ('POCA') which contains the core offences. The Act prohibits the creation and dissemination of indecent images of children in the form of photographs and pseudo-photographs. Possession of an indecent photograph is criminalised separately under the Criminal Justice Act 1988 s160. Under the POCA, it is an offence:

(a) to take, or permit to be taken [ or to make], any indecent photograph [ or pseudophotograph] of a child $[\ldots]$ 
A pseudo-photograph is 'an image, whether made by computer graphics or otherwise howsoever, which appears to be a photograph' (s 7(7) as inserted by CJPOA 1994). The pseudo-photography amendment was intended to catch those who aim to evade the law by using software packages to produce images instead of a camera, especially as such images can be virtually indistinguishable from photographs (Gillespie 2011, 48-50).The main POCA offence thus requires an indecent photograph or pseudo-photograph of a child. As will be illustrated below, some of these terms pose some problems for solid three-dimensional artefacts.

\section{'Indecent'}

Indecency is not defined in the POCA. It is left to the jury, to be evaluated against recognised standards of propriety and as a matter of degree (Gillespie 2011, 51-4; see also $R v$ Graham-Kerr [1988] 1 WLR 1098; $R$ v Smethurst [2002]1 Cr App R 6; $R v$ O'Carroll [2003] EWCA Crim 2338). However, this lack of specificity may not be problematic in the case of child sex dolls and robots. Although it could not be presumed, it is likely that child dolls and robots with realistic genitalia and/or penetrable orifices would be considered indecent under the POCA as they have been under the emerging CCA cases, where the term is similarly undefined (see further Matthews 2019). ${ }^{9}$

\section{'Photograph or pseudo-photograph'}

For child sex dolls and robots to be covered by the POCA, the term 'photograph' would have to be construed so as to cover three-dimensional artefacts, but this interpretation is difficult to achieve. In $R v$ Fellows and Arnold the dictionary definition of photograph was cited as "a picture or other image obtained by the chemical action of light or other radiation on specially sensitised material such as film or glass" ([1997] 1 Cr.App.R 244, 253) and the case does make clear that the language of the POCA could accommodate certain developments in technology where they post-dated the statute (Gillespie 2011, 48). Section 7 adds further detail, clarifying that 'photograph' includes moving and digitally created images. However, it is questionable as to whether a tangible threedimensional artefact such as a child sex doll is a 'photograph' or could be construed as an 'image'. The OED lists 'image' and 'sculpture' as synonyms, ${ }^{10}$ however, the example sentences given as illustrative of the term 'image' indicate that although related, sculpture and image are separate concepts, in that the sculpture is the tangible three-dimensional 
rendering of an image. Given that the mischief the Act focuses on is that of the image/photograph, it is thus unlikely that 'photograph' and 'image' would have been intended to encompass a solid three-dimensional form, or that they might be made to do so through generous statutory interpretation. Arguably holograms, being generated images, could be included (Gillespie 2011) and it is arguably likely that they will be increasingly used in the creation of explicit three-dimensional imagery of children as the technology develops. ${ }^{11}$ Nonetheless, the conceptual distinction between a generated holographic image of a child and a tangible physical representation such as a doll or robot implies that whilst holography and VR may be encompassed by the statutory language of the POCA, robots and dolls would not be.

Considering methods of production, a doll or robot would most likely be created using photographs put through a computer programme. They could also possibly be created from a scan of the child's body. Aside from any photograph initially involved, the storage of bare electronic data from a scan or programme to create a replica is arguably already covered by the law, in that the POCA interprets photograph to include 'data stored on a computer disc or by other electronic means which is capable of conversion into a photograph', and it will be recalled that the pseudo-photography clause covers computergenerated photographic-quality images $(\mathrm{s} 7(4)(\mathrm{b})$ as inserted by the Criminal Justice and Public Order Act 1994). ${ }^{12}$ However, the final 3D artefact produced would be unlikely to be covered due to the difficulties posed by the term 'photograph' as noted above.

Considering manual sculptural processes, where a doll or external skin of a robot was created by a silicone cast or mould, the law of battery could be considered if a real child was used, also sexual assault under the Sexual Offences Act 2003, where s78 establishes that:

"For the purposes of this Part... penetration, touching or any other activity is sexual if a reasonable person would consider that-

(a) whatever its circumstances or any person's purpose in relation to it, it is because of its nature sexual, or

(b) because of its nature it may be sexual and because of its circumstances or the purpose of any person in relation to it (or both) it is sexual." 13 
However, the s78 offence would not cover the solid artefact produced. Nor would it cover a doll or robot created by manual sculptural process or an item made at home by mosaicking toy dolls with sex toys, where, in either case, no child was touched. ${ }^{14}$ As before, the language of photography would also exclude all such items from the POCA.

\section{'A child'}

The POCA defines a child as someone under 18 and determining this is a question for the jury (s7(6); for critique see Gillespie 2011). Whilst it may be less clear as to how to evaluate age in photographs, arguably three-dimensional representations are likely to pose fewer problems in this respect as their purpose is to be a realistic and life-sized model of a child, with commercially-manufactured models aiming to have accurate characteristics such as weight and height, such clues being less apparent (or in the case of weight, absent) from photographs. An interesting question arises in relation to where dolls or robots are created to have hybrid characteristics such as some physical elements of a child mixed in with other non-humanoid attributes. ${ }^{15}$ The possibility of fantasy/hybrid or imaginary representations has been addressed in separate legislation designed to address non-photographic sexualised representations of children, to which I now turn.

\section{The Coroners and Justice Act 2009}

Taking a different approach to the POCA, the Coroners and Justice Act ('CoJA') offence abandons the language of indecency and photography, and creates the new offence of possessing prohibited images of children (s62; see Ost 2010; Al-Alosi 2018; Strikwerda 2016). The new offence was motivated by concerns that non-photographic images of child abuse such as cartoon depictions were frequently found alongside illegal photographic collections, but that the law only covered the latter (Home Office 2007; Ost 2010). Whilst it was acknowledged that such images do not cause direct harm to real children in their creation, the legislature was persuaded to act by arguments suggesting that cartoon-like or fantasy imagery could be used in grooming, and that such material might reinforce inappropriate desires towards children (Home Office 2007, 6). In order to distinguish the new offence from the POCA and its aim of preventing the harms caused by the creation of indecent photographs (in that the photograph itself is the catalogue of 
actual harm to a real child) and the fact that it is a simple possession offence, the CoJA offence carries a lesser penalty of three years' imprisonment (s66; see also Home Office 2007, 9). The most relevant elements of the offence require that the image is pornographic, that it is grossly offensive, disgusting or otherwise of an obscene character, and that it is an image which focuses solely or principally on a child's genitals or anal region (CoJA s62 (1),(2),(6)). 'Pornographic' is defined as being 'of such a nature that it must reasonably be assumed to have been produced solely or principally for the purpose of sexual arousal' (CoJA s62(3) see also Al-Alosi 2018, 54) and a 'child' is a person under the age of 18 (CoJA s65(5). An image of a child can be where "the impression conveyed by the image is that the person shown is a child... or the predominant impression conveyed is that the person shown is a child despite the fact that some of the physical characteristics shown are not those of a child' (CoJA s65(6) see also s65(8). 'Image' means a moving or still image which is produced by any means (CoJA 65(2)).

\section{'Image'; 'pornographic'; 'focus' and 'child'}

Might the CoJA offence be used to cover child sex dolls and robots? Arguably the character of child sex dolls and robots may readily meet the gross offensiveness/pornographic and focus requirements. If dolls or robots were created to have hybrid characteristics such as some physical elements of a child mixed in with other non-humanoid attributes, this could be caught by the CoJA offence if the predominant impression were childlike. However, as commentators have noted in relation to twodimensional fantasy child pornography, whilst the 'reasonable doubt' threshold acts as a safeguard, the lack of statutory guidance on how 'human' the image must be creates a degree of uncertainty as to where the line is drawn in practise (Al-Alosi 2018,49-52). Moreover, as with the POCA, success would be dependent on a strained interpretation of 'image'. ${ }^{16}$

\section{The Sexual Offences Act 2003}

As noted above, one of the rationales for the CoJA offence was to prevent grooming. Given that child sex dolls and robots could be used for sexual solicitation it is worth considering whether and how they might be caught by other grooming-related offences. S12 of the Sexual Offences Act ('SOA') creates the offence of causing a child to watch an image of sexual activity: 
A person aged 18 or over (A) commits an offence if

(a) for the purposes of obtaining sexual gratification, he intentionally causes another person (B)...to look at an image of any person engaging in activity,

(b) the activity is sexual...

'Image' is defined as 'an image produced by any means and, where the context permits, a three-dimensional image' thus appearing to speak to holograms (s79(4) see further Gillespie 2011, 109). However, as previously, the language of imagery infers that the inclusion of dolls and robots would be unlikely. Even if accepted as 'images', the requirement of 'activity' might be restrictive, in that whilst this may cover physical interactions with such a robot or doll, the doll or robot in itself would not appear to be covered. S12 could not thus be considered to criminalise bare possession as such, as it would be restricted to where materials were used in a grooming context. S10 SOA (causing or inciting a child to engage in sexual activity) could potentially be relevant where a robot was given to a child and used as a proxy for the offender's own actions, for example where the robot was communicative and could relay speech and film, or where it was interactively linked to a remotely located sex toy used by the offender. Given that the broader definition of the SOA was deliberately adopted to reflect concerns raised by the police that sex offenders often used media other than photographs to show to children (Hansard HC 2002-03 Standing Committee B part 7 Col 127 at Col 150), and considering how closely sex dolls and robots could resemble children and children's toys, and thus readily be deployed as part of grooming strategies to normalise sexualised behaviour, it is appropriate that they come under the ambit of offences related to grooming. S143 of the Powers of Criminal Courts (Sentencing) Act 2000 forfeiture provisions could be used to remove the items from offenders, ${ }^{17}$ but under both s12 and S10 SOA it is notable that the criminality would be in relation to the incitement and not attached to the doll or robot itself, leaving bare possession and creation/trade unaddressed.

\section{Obscenity laws and Communications Offences}

Thus far, the analysis has demonstrated that there are some problems with the current child protection framework. However, obscenity law might be considered as an alternative. As it is based on historic offences that have evolved over centuries to cover a wide variety of material, obscenity law is not constrained in the same way that the child 
protection regime has been. Whilst the obscenity laws predate the emergence of the specific child protection regime, they can be used in conjunction with it $(R v S(G)$ (2012) 2 Cr.App.R. 14 CA). However, as will be shown, these laws are not without difficulties.

\section{'Obscene' and 'article'}

The Obscene Publications Act 1959 states that:

(1) For the purposes of this Act an article shall be deemed to be obscene if its effect or (where the article comprises two or more distinct items) the effect of any one of its items is, if taken as a whole, such as to tend to deprave and corrupt persons who are likely, having regard to all relevant circumstances, to read, see or hear the matter contained or embodied in it.

(2) In this Act "article" means any description of article containing or embodying matter to be read or looked at or both...

'Article' is clearly less restrictive than the word 'photograph' from the POCA offence, and Scottish obscenity legislation speaks of 'obscene material', which has been interpreted to cover "representations and models" (Conegate Ltd. v HM Customs and Excise [1987] QB 254). ${ }^{18}$ Accordingly, obscenity legislation could more readily be interpreted to address child sex dolls and robots. The question of what 'child' means would not be relevant, as obscenity law does not require the material to be of a child, and the requirement of obscenity is very broad as it does not require any sort of sexual element at all (Gillespie $2011,150)$. It will be recalled that the CCA s42 uses the terminology of obscenity in that it prohibits the importation of 'indecent and obscene articles', but the terms do not read across the statutes. In Henn and Darby v DPP ([1980] 2 W.L.R. 597) it was observed that the terminology in the CCA and the OPA does not have equivalence, in that 'indecent and obscene' in the CCA refer to the broader concept of 'offending against recognised standards of propriety, generally but not exclusively with reference to sexual matters, "indecent" being at the lower end, and "obscene" at the upper end of the scale" whereas "obscene" used as a singular term in the OPA referred to a narrower understanding, namely material which tends to deprave and corrupt the viewer. CCA cases do not thus guarantee a finding of obscenity under the OPA but having said this, whilst the 'deprave and corrupt' test of obscenity is a jury question and thus could not be taken as read, if it 
were suspected that the dolls or robots were or could be being used for grooming purposes and were clearly sexualised objects, then the possibility of children being depraved and corrupted as the likely audience in particular would probably prove persuasive for a jury. Where instructions to create a doll or robot were sent as software to a $3 \mathrm{D}$ printer or other computerised manufacturing means, the OPA could again be relevant, in that it covers the use of 'negatives, etc. for the production of obscene articles' (1964 s2(1)). This covers 'anything which is intended to be used, either alone or as one of a set, for the reproduction or manufacture therefrom of articles containing or embodying matter to be read, looked at or listened to, as if it were an article containing or embodying that matter so far as that matter is to be derived from it or from the set' (1964 s2(1)).

\section{'Publication'}

Obscenity law also requires publication, where the publisher 'distributes, circulates, sells, lets on hire, gives, or lends it, or who offers it for sale or for letting on hire' or 'in the case of an article containing or embodying matter to be looked at or a record, shows, plays or projects it...' (OPA 1959 1(3)(a)(b)). Publication is interpreted as meaning whether for gain or not, or possession for publication for gain where gain is interpreted as including non-financial consideration (OPA 1959 2; 1964 1(5)). If it can be argued that the child sex doll or robot is conveyed to another in a manner as described in the offence, then this may be suggested as fulfilling the publication requirement. ${ }^{19}$ However, it would not cover the domestic creation of a doll or robot solely for private use. ${ }^{20}$

\section{Domestic transfer}

Whilst we now know customs legislation addresses the importation of child sex dolls, if they were to be manufactured domestically, transfer would likely depend on the post, in which case existing postal legislation could be also used. The Postal Services Act 2000 s85(3)(b) prohibits the sending of an obscene article, the definition of which is not restricted to two-dimensional matter. As under postal legislation obscenity takes its dictionary definition, finding the article in question to be obscene may be relatively straightforward. ${ }^{21}$ However, detection would be a challenge as there are less stringent checks on mail sent domestically than internationally. 


\section{Could and should child sex dolls and robots be criminalised? The wider context}

Until this point, I have sought to demonstrate that the existing framework does not adequately or convincingly cover child sex dolls and robots. ${ }^{22}$ The POCA could in theory address the most but would depend on a very strained interpretation of photography/imagery to achieve this. The CoJA does not require photography but still focuses on images, thus it too would be unlikely to cover dolls and robots and is purely a crime of possession. The SOA also dwells on imagery, addresses possession obliquely at best, and then only within the context of grooming activity. The most likely of the legislation considered to cover dolls and robots is the OPA which avoids the terminology of imagery entirely, but is restricted to publication and fails to address bare possession, ${ }^{23}$ whereas the postal legislation would likely cover dolls and robots but only deals with distribution.

The importation cases clearly indicate that the likely trajectory of the law will be to expand to include child sex dolls and robots, a move that would resonate with calls for their prohibition. ${ }^{24}$ However, if the law is to develop on a principled and coherent basis, and in a manner that avoids the problems of the current framework, then the rationale for criminalisation should be carefully considered. Any extension of the criminal law, whether by the expansion of current offences or the creation of new ones, warrants the examination of the underlying justifications for such actions, as the form and limits of the law will be shaped by the rationale used in support. Looking to theories of criminal law, it is generally accepted that as the severest sanction of the state, the criminal law should only be invoked on defensible grounds (Smith and Hogan, 1999; Child and Ormerod, 2015; Lacey and Wells 1998; compare Hillyard et al. 2005). Accordingly, discussion of whether and how criminalisation might be justified is necessary in order to inform the law's response.

\section{What harm is caused by child sex dolls and robots?}

In existing work on child pornography, legal academics have explored various theories behind criminalisation and these analyses may be usefully drawn on here (Ost 2009, 2010; Gillespie 2011). Where real children are involved in the production of indecent photographs, an argument often drawn on to justify criminalisation is the liberal harm 
principle, whereby only the harm caused to others by an individual's behaviour can warrant state interference with that individual's liberty (Mill 1998, Ost 2010; Feinberg 1984, 1985). ${ }^{25}$ Harm under the principle can be defined as harm in the sense of an injury or as a setback to someone's interests (Ost 2009, 126; Feinberg 1984). ${ }^{26}$

Using this principle, establishing that harm is caused by the creation of indecent photographs is straightforward: children are harmed physically and/or psychologically in the process (Ost 2009; Gillespie 2011) and such images encourage the sexual objectification of children whilst masking their lack of capacity to consent. Accordingly, criminal sanctions are legitimate and appropriate. Dissemination and possession cause secondary harm which flows from their connection to the act of creation. Dissemination perpetuates and amplifies harm though the circulation of images, likewise possession can be seen to cause secondary victimisation in that: 'the possessor exploits the child since, by possessing the image, he is taking unfair advantage of her and using her as a means to an end...it underwrites the severe primary harm' (Ost 2009, 123). ${ }^{27}$ Possession has also been linked to the creation of new material as the purchaser seeks to expand their collection, and it can be a useful offence for law enforcement agents as it is easier to prove and can be an alternative offence where material is discovered but evidence of intended distribution is lacking (Gillespie 2011, 34; Ost 2010, 246).

Does this argument read across to child sex dolls and robots? It is important to dwell on what the harm in this context might be, as unlike indecent photographs, it is not so immediately apparent. If the doll or robot was the catalogue of the child's coercion and/or a record of sexual posing, then arguably direct harm could be demonstrated and thus criminalisation would clearly be appropriate. However, unlike photography it is less likely that the child will be so manipulated in that all that is needed is a physical resemblance; the whole point of the doll or robot is to supply the rest. If a person were to create a sex doll or robot from a photograph of a child from life or from a picture of them found online, how might they be harming that child?

Whilst child sex dolls and robots created in this manner would not be a primary record of abuse in the way that 'traditional' i.e. photograph-based child pornography is, it is nonetheless arguable that if a sex doll or robot was based on a real child, harm could 
still be established by this illegitimate use of their image for sexual purposes. In such a case, the nature of the harm would likely be psychological. Particularly given its purpose, knowledge of the facsimile could feasibly cause serious psychological harm to the child it was based on; harm which could be magnified by the increased degree of realism which 3D technology provides. Dolls can be tailored to specification and it may be very clear from the appearance of the doll that a real child has been used as a template, for example where the item has been made to order from a photograph or scan, or where based on a well-known public figure. ${ }^{28}$ The addition of robotics could further amplify this impression of reality as could the development of deepfake technology. ${ }^{29}$ It is entirely feasible that a voice-recognition app combined with AI could create personalised mannerisms and gestures that would give ever-greater verisimilitude. Moreover, at the time of writing 3D printing can now be done with living cells (Dale 2018). Artificial human skin is already grown, and there is an increasing push towards developing labgrown or 'cultured' meat for human consumption (IFL Science, n.d.; Pasha-Robinson 2018). When combined with live cell printing, the possibility of such developments in the field of tissue engineering could mean that it is not outlandish to speculate that entire body parts and even whole bodies could be recreated (Devlin 2017). The next step may be the possibility of a flesh-based sex robot, where the existence and knowledge of such a 'meat-clone' or 'bio-doll' created for sexual purposes could feasibly be even more distressing still. ${ }^{30}$

Regardless of the substrate, the creation of what would essentially be a copy of a child for sexual purposes would arguably also be an interference with the child's right to not be treated as a sexual object for an exploiter, and the right to have control over their own image; to self-determination and dignity. ${ }^{31}$ Arguably, this harm could arise regardless of whether the child was aware or unaware of the object's existence. In a recent piece on the non-consensual creation and/or distribution of private adult sexual images, a phenomenon sometimes known as 'revenge porn', McGlynn and Rackley $(2017,546)$ elaborate on the concept of dignity, noting that:

'image-based sexual abuse violates the dignity of victim-survivors by its deliberate infringement of their self-worth and failure to treat them with respect...dignity...is violated simply by a 'failure to show respect to the individual as an equal in 
society', regardless of the fact that she may also have suffered physical, psychological or financial harms. Nor need she experience or demonstrate distress or anger.'

As such, the violation of dignity could occur in cases where the child was not touched or otherwise harmed in the process of creating the doll or robot, or was even aware of its creation. Arguably, knowledge of harm cannot be a precondition of the violation, as if it were to be, integrity and dignity would lack universality and effectively be evacuated of all meaning. ${ }^{32}$

The above arguments demonstrate that the creation of a child sex doll or robot based on a real child can indeed be seen as harmful. Accordingly, the secondary harms of distribution and possession follow. In relation to possession, as noted above, the fuel argument is sometimes cited, where consumption is linked to demand and inevitably the production of fresh material (Gillespie 2011, 37). Due to space, storage and method of production and their capacity to be interactive and customisable, it is unlikely that dolls and robots would be collected on the same scale as digital images. However, it is arguable that the scale of any collection should be irrelevant to the question of whether criminalising possession is justified. Harm is established in that the possessor is underwriting and profiting from the harm initially caused by the creator. Moreover, it would be undesirable to set a threshold of what size of collection would be acceptable. ${ }^{33}$

Whether criminalisation can be justified (and if it can, to what extent) where no real child is involved is a more difficult question to answer. As noted above, the domestic law has already moved to include purely fantasy images through the $\mathrm{CoJA}^{34}$ but this was a highly contested development. When the government consulted on the creation of a new offence for purely imaginary non-photographic pornographic material - a measure eventually enacted by the CoJA - opinion was divided as to whether it was appropriate to criminalise at all where no real child was involved and that as a possession offence, it unjustifiably trespassed on freedom of expression in the private domain (Home Office, 2007; see also Ost 2010). 
Can the debates on purely fantasy child pornography inform our thinking on where the limits of the law should lie? In drawing parallels, Strikwerda (2016) considers the criminalisation of fantasy child pornography as supportive of the argument that child sex robots should be treated likewise. ${ }^{35}$ She argues (2016) that both depict fantasy children in sexualised contexts and are similar because both are considered to lack a legal or moral victim. As such, she considers (2016) that the classic liberal harm principle does not apply, in that the sex robots themselves are not capable of being harmed by the actions of their users, thus harm to another is not being caused. Despite this, drawing on feminist anti-pornography discourse and virtue ethics, she builds a case (2016) that both fantasy child pornography and child sex robots provide a depiction/facilitation of fundamentally unequal, disembodied, unresponsive and passive sexual encounters which flout our preferred sexual value system that is based on equality, embodiment, consent and respect for the person. ${ }^{36}$ Accordingly, both fantasy child pornography and child sex robots can be found morally objectionable, and legal moralism permits us to use moral grounds to justify the criminalisation of both fantasy child pornography and child sex robots (Strikwerda 2016). This argument is echoed by Danaher, who contends that legal moralism can justify prohibition of the use of child sex robots as such actions can be seen to express a deficient moral character on behalf of the users, and that moral paternalism can be invoked as a protective measure: 'there are reasons for thinking that such usage harms moral character...[and] enjoyment of such acts evinces a disturbing insensitivity to important social moral issues' $(2017,93)$. On the grounds of legal moralism and paternalism, the law can be used to steer society in a respectful and caring direction. ${ }^{37}$

In contrast, proponents of the Millian liberal harm-based principle have expressed their doubts as to the legitimacy of criminalisation in a context where there is no concrete harm to an actual child and reject legal moralism and paternalism as an appropriate basis for legislation (Ost 2010; see also Gillespie 2011). For example, Ost (2010) roundly critiques the CoJA for the introduction of a victimless crime and questions whether it actually prevents any harm to anyone. She argues (2010) that a morality/paternalismbased jurisprudence is an unjustified and unconvincing restriction on liberty and freedom of expression, in that prohibition should be reserved for behaviour that causes actual harm, and not be based on the principles of community disgust, distaste or outrage. 
One of the commercial manufacturers of child sex dolls, who himself identifies as a paedophile (discussed in Morin 2016) argues that such items are therapeutic and diversionary, but this position is strongly challenged by children's charities such as the NSPCC (Guilbert 2018). Although seemingly at odds, both positions could hold some truth. A leading psychiatrist Seto observes that: 'for some pedophiles, access to artificial child pornography or to child sex dolls could be a safer outlet for their sexual urges, reducing the likelihood that they would seek out child pornography or sex with real children. For others, having these substitutes might only aggravate their sense of frustration' (Seto as quoted in Morin 2016). In sum, there is a lack of evidence as to whether the use of child sex dolls or robots would increase or reduce contact offences or the acquisition of real material. A morality-based argument would not be bolstered by any therapy/deflection argument, as the objectionable nature of the material (whether real or imaginary) would outweigh any therapeutic benefit. However, from a liberal harmbased perspective, it would appear that abstract child sex dolls and robots should be permitted unless real, tangible harm to another can be established.

Yet perhaps it is a mistake to see matters of harm and morality as mutually exclusive. As Al-Alosi contends in her analysis of fantasy child pornography, criminalisation may be seen as encompassing considerations of both, and that such qualities are not easily separable or distinct $(2018,130)$. She argues that even if laws targeting this material are morally motivated, this fact alone does not invalidate them, in that: 'much of the criminal law is based on moral conceptions of right and wrong and the mere fact that a law is grounded in morality does not automatically render it illegitimate' (2018, 130, citing $R v$ Butler [1992]1 SCR 452 at 493). Moreover, the law has an important symbolic function in expressing shared social values; in this case, the condemnation of material that degrades and dehumanises children (Al-Alosi 2018, 131). Noting that 'it has become almost a cliché' (Al-Alosi 2018, 130) to point to the absence of evidence in debates on the harms of fantasy child pornography, she argues that such evidence is impossible to obtain due to the ethical and legal barriers to conducting it, and a lack of evidence of harm does not necessarily mean that the material is therefore harmless $(2018,130)$. Citing Taylor and Quayle, she states that although studies on harm are not conclusive, given the seriousness of child sexual abuse, "perhaps we should "err on the side of caution and assume the balance lies in terms of the dangers of fantasy 
becoming a reality"' (Al-Alosi 2018, 130). It rather depends on how harm is construed, and in this vein she suggests that the harm principle might be construed more broadly to encompass harms felt by the body politic (Al-Alosi 2018, 110).

In their article exploring revenge pornography, McGlynn and Rackely articulate the concept of 'cultural harm' that the creation and circulation of non-consensual adult sexual private images promote (McGlynn and Rackley 2017). This type of harm describes the wider repercussive effect of such images extending beyond the individual, namely the fostering of a damaging set of social attitudes, particularly felt by women and girls, where sexual consent is regularly ignored and indeed normalised. As a lack of consent becomes normalised, an environment is created that takes acts of sexual violence less seriously (McGlynn and Rackley 2017). Drawing on this reasoning, Al-Alosi suggests that the harm principle can be validly interpreted to justify the criminalisation of purely fantasy child pornography, in that it promotes a damaging culture of the sexualisation of children and that the rationale for prohibition can in fact be seen as multifaceted; validly incorporating elements of morality $(2018,130)$. In considering where to draw the line, she suggests that whilst prohibiting dissemination can be justified on the harm grounds as outlined above, it is difficult to extend this to material that is self-created purely for private use and never circulated, in that nobody else is aware of its existence thus it does not contribute to a damaging public culture of harm (Al-Alosi 2018, 131-2). This exception would give some respect to freedom of expression and privacy, and could be asserted without inferring the need for any correlative right of access. Likewise it could be disapplied where there was intent to disseminate (Al-Alosi 2018, 131).

Such reasoning is arguably applicable to fantasy child sex dolls and robots. Whilst like fantasy child abuse imagery they would not cause harm of the same magnitude as real abuse imagery, they may still be seen as causing harm. Following the cultural harms argument, permitting a trade in even abstract child sex dolls and robots could be seen as sanctioning and facilitating a public atmosphere that encourages the portrayal of children as sexual objects, and the acceptance and normalisation of child abuse. ${ }^{38}$ Excepting selfproduced articles that are intended for private use and never enter the public sphere seems to strike a justifiable balance between the wider aims of preventing the harms outlined above and has at least some respect for the privacy and freedom of expression of the 
individual. As Al-Alosi notes $(2018,132)$, it is difficult in practise to enforcing laws that criminalise the private possession of self-authored material unless there is a high degree of surveillance of peoples' homes, and the likelihood of detection would be very low if they kept the material private. If there was evidence that the private items were intended to be used in grooming, then the exception could be disapplied.

\section{What should the law look like?}

If the arguments above are accepted, then we can validly criminalise the creation, dissemination and possession of child sex dolls and robots that are based on real children. We can also validly criminalise the dissemination of abstract dolls and robots, and their creation/possession where there is intent to disseminate. Yet how might the law achieve this? It will be recalled that the current framework is not up to the task of regulating child sex dolls and robots for a number of reasons, namely the focus on imagery, lack of emphasis on sexual purpose, and restrictions in ambit. Rather than amend the POCA, it is suggested that the best way to proceed would be to draw on the SOA provisions as scaffolding for new offences. Borrowing elements of the SOA's existing offences could serve to highlight the specifically sexual purposes of these dolls and robots. It would also avoid having to shoehorn new concepts into the POCA, CoJA or OPAs when their definitions were never intended to stretch that far.

The choice of terminology is a challenge. Various definitions of child sex dolls and robots have emerged that could be considered. The Campaign against Child Sex Robots defines them as 'machines in the form of women or children for use as sex objects, substitutes for human partners or prostituted persons' (https://campaignagainstsexrobots.org/about/). ${ }^{39}$ Danaher's definition is more detailed, a sex robot being: 'any artefact that is used for sexual stimulation and/or release with the following three properties: (1) a humanoid form; (2) the ability to move; and (3) some degree of artificial intelligence (i.e. some ability to sense, process and respond to signals in its surrounding environment)' and a child sex robot as 'a robot that looks and acts like a child' $(2017,72)$. However, neither definition covers dolls. Matthews (2019) notes that the Australian Department of Immigration and Border Protection publishes guidance on prohibited imports that specifically mentions dolls where they appear to be manufactured for a sexual purpose and appear to be a depiction of a child under 18 , but this would not 
address robots. The only statutory definition I could find that covers both is the American CREEPER (“Curbing Realistic Exploitative Electronic Pedophilic Robots”) Act 2017, which addresses the importation and transportation of any 'anatomically-correct doll, mannequin, or robot, with the features of, or with features that resemble those of, a minor, intended for use in sexual acts. ${ }^{40}$ However, the term 'minor' is imprecise for domestic purposes.

Rather than use any of these, I suggest that all the above should be rejected on the grounds that terms like 'child sex doll' and 'child sex robot' ought not to be used in any new offences. Whilst the literature in the area is heavily reliant on the terminology of sex dolls and robots, and the discussion thus far has therefore had to reflect that, the difference between the two or what is meant by either is not always clearly articulated. Whilst a sex doll might be defined at base as one that lacks any electronic and/or robotic element, at what stage a sex doll becomes a sex robot and the degree of electronic enhancement required is unclear. Arguably the line between the two is increasingly blurred in that a doll may be roboticised or otherwise technologically enhanced to varying degrees, and both may look visually identical. ${ }^{41}$ Essentially, both are simulated children, and the use of such terminology rather than child sex doll or robot avoids the problems of differentiating the two and becoming overly-focused on any particular media or method of creation.

Accordingly, under the SOA, there could be new offences of creating, distributing and possessing a simulated child for the purposes of sexual activity. The definition of 'simulated child' could be 'any object intended to simulate a child, howsoever produced' which would avoid a focus on particular methods of manufacture or media, and should be able to cover any advances in materials technology. Akin to the POCA offences, this offence would target those instances where it seemed apparent that a real child was used and the upper sentencing limit should reflect the POCA offences as the harms could arguably be of the same magnitude. It could be objected that as dolls and robots become ever more realistic, it might become difficult for prosecutors to establish whether a real child has been involved in any stage of production at all. However, this problem can be dealt with in defences; the legislature could adopt Ost's $(2009,131)$ suggestion of creating a defence whereby, if the accused can prove that the material is completely fabricated, 
then there will be no offence under this particular provision. Such a burden on the accused is justifiable in that as they have chosen to possess such an object in ignorance of the context of its creation, then they are choosing to run the risk that it involved a real child (Ost 2009, 131).

The age range of 'child' varies in the SOA depending on the offence, but if the justification for prohibiting simulated children is the same as that of prohibiting indecent imagery then the same age limits ought to apply to both, thus the definition of child under the POCA (i.e. under 18) should be adopted for this particular offence. Whilst it could be argued that this threshold effectively lumps together different offending groups (paedophiles, hebephiles and ephebephiles) who have different psychological profiles and risks, ${ }^{42}$ there are problems with these categories too, in that basing the law around biological characteristics and/or psychological offending profiles may not get us any further (see Gillespie 2011, 12-8, 218-42). Whilst it is accepted that the law is inconsistent on the question of age (such as the age of consent being lower) and that there may be different considerations at the upper end of the age scale, particularly with adolescents, the choice of 18 would chime with other child protection offences and broadly be in line with international instruments on child protection such as the Convention on the Rights of the Child (Gillespie 2011). The criminal threshold of reasonable doubt could also help to avoid any ambiguity regarding what age the item appeared to depict (Al-Alosi 2018, 49).

The CoJA definition of a child to include 'predominant impression of a child' could be used in a separate set of offence to address the creation and possession of abstract dolls and robots where there is a view to dissemination (whether or not for gain), and the act of dissemination itself. Whilst it has been noted that the lack of definition on how child-like the item must be means a degree of uncertainty in practise, it would be very difficult to have more precision and it is hard to think of how else this could be drafted. Having separate offences relating to the trade in purely fantasy material would reflect the different harms and nature of that material, and they should also have a lower sentence matched to those of the CoJA. As already discussed, the offences should be contoured so as to exclude private material that was created purely for personal use. Any sharing online (e.g. uploading video of a home-made doll) should be covered by the offence, as it brings 
the item into the public domain. The age threshold for these offences should also be 18 for the reasons outlined above.

For both sets of offences (real and abstract), for purposes of sexual activity could follow the definition in SOA s78 as already described, that is to say "an activity is sexual if a reasonable person would consider that- (a) whatever its circumstances or any person's purpose in relation to it, it is because of its nature sexual, or (b) because of its nature it may be sexual and because of its circumstances or the purpose of any person in relation to it (or both) it is sexual." Insisting that the simulated child was produced for sexual purposes avoids including items such as those described above produced for innocent purposes, and keeps a focus on sexualised simulations. It also draws a line between objects intended to simulate children in a sexual manner and other items such as genuine toy dolls and artworks. It also excludes small sex toys, which do not represent children a clear way and may have a range of legitimate uses. ${ }^{43}$

\section{Conclusion}

Child sex dolls are now appearing openly on the commercial marketplace, and there are increasing concerns that the law is inadequately prepared for them and their robotic counterparts. What this article makes clear is that the legal questions prompted by the advent of child sex dolls and robots are imminent, and need considering now. Against a background of sparse scholarly commentary and lack of legal clarity in this area, this article has thus sought to break ground by exploring two key and interlinked questions, namely; could and should child sex dolls and robots be criminalised within the child protection framework? Using the principal statutes in the area, this article has reviewed the core offences of creation, distribution and possession, and considered where child sex dolls and robots might lie. It argues that they cannot be fitted neatly into a framework largely predicated on two-dimensional renderings, and that current statutory language in particular makes the law largely unsuitable. It seems counterintuitive that a twodimensional sexualised representation of a child is criminalised but the identical representation in three dimensions would not be, yet that is exactly the conclusion to be drawn unless the law is changed. 
The article has thus proposed new offences under the SOA to address the gaps. In justifying criminalisation, has been argued that the prohibition of child sex dolls and robots where real children are involved can be validly done under the classic liberal harm principle. The creation of the artefact may involve physical and/or psychological harm, and even where it does not, the fact of its creation interferes with the child's right not be exploited, and compromises their dignity and integrity. Dissemination and possession underwrite these harms. Whilst the case for criminalising abstract dolls and robots is less apparent at first glance, I have argued, echoing Al-Alosi (2018), that even fantasy child sex dolls and robots cause harm by creating a culture where the sexualisation of children is normalised and legitimated. This wider cultural harm can justify the creation and possession of such items where there is an intent to trade or distribute, and the criminalisation of such distribution. However, it has also been argued that on the wider cultural harms grounds it is difficult to justify criminalising the possession of self-created fantasy dolls and robots that are only ever intended for private use, and that there should be an exception for this that acknowledges that in the absence of harm the law ought not to intrude on the private sphere.

*Dr Bela Bonita Chatterjee, Centre for Crime, Law and Justice, Lancaster University Law School, Lancaster LA1 4YN b.chatterjee@lancaster.ac.uk. My thanks to Catherine Easton, Agata Fijalkowski, Alisdair Gillespie and Suzanne Ost for discussion in relation to this article. I am also grateful to the anonymous reviewers for their valuable observations and suggestions. Any errors are my own.

Notes

English and Welsh cases

Conegate Ltd. v HM Customs and Excise [1987] QB 254

Henn and Darby $v$ DPP [1980] 2 WLR 597

$P v$ Cheshire West \& Cheshire Council; $P \& Q$ v Surrey County Council [2014] UKSC 19

$R v$ Charnock (unreported)

$R v$ Dobson (unreported)

$R v$ Doel (unreported)

$R v$ Fellows and Arnold [1997] 1 Cr.App.R 244

$R v$ GS [2012] EWCA Crim 398

$R$ v Graham-Kerr [1988] 1 WLR 1098

$R v O^{\prime}$ Carroll [2003] EWCA Crim 2338

$R v S(G)$ (2012) 2 Cr.App.R. 14 CA

$R v$ Smethurst [2002]1 Cr App R 6 
$R v$ Turner (unreported)

$\underline{\text { Australian cases }}$

$R v$ Miao [2016] NSWDC 181

\section{$\underline{\text { Canadian cases }}$}

$R v$ Butler [1992]1 SCR 452

English and Welsh legislation

Coroners and Justice Act 2009

Criminal Justice Act 1988

Criminal Justice and Public Order Act 1994

Customs and Excise Management Act 1970

Customs Consolidation Act 1876

Obscene Publications Act 1959

Obscene Publications Act 1964

Postal Services Act 2000

Powers of Criminal Courts (Sentencing) Act 2000

Protection of Children Act 1978

Sexual Offences Act 2003

\section{$\underline{\text { American legislation }}$}

CREEPER (“Curbing Realistic Exploitative Electronic Pedophilic Robots”) Act 2017

\footnotetext{
${ }^{1}$ Machineware is already commercially available to create (non-sexualised) $3 \mathrm{~d}$ replicas, see e.g. www.3ders.org; https://www.shapify.me/partner/booth (3d Scanning booth which produces 'shapies'). There are numerous options that cater for the adult sex doll market which give an idea of the degree of customisation available, see e.g. Silicon Wives Luxury Sex Dolls ('Send us pictures, measurements, and descriptions of the features you want and we'll build you a sex doll to match')

https://www.siliconwives.com/pages/custom-sex-dolls-design-your-dream-girl Notably the site states no child sex dolls are permitted.

${ }^{2}$ According to the Sun newspaper (see du Cann 2018) the Harmony Doll, controllable by the additional purchase of the RealDoll app, was ready to ship for Christmas 2018. The doll features a posable body with animated head (see also The Guardian 2017). The title of the world's first sex robot is also claimed by the Roxxxy, as mentioned in the Guardian (2017). The Guardian (2017) notes that although customers could purchase Roxxxy for just under ten thousand dollars, nobody has ever reported owning one (see
} 
also Cheok and Levy 2017; Sharkey et al. 2016; Guitu 2016). Commentators appear to agree that the technology for robots is in its infancy and the current state of the art for adult materials at least would more accurately be described as dolls with elements of limited roboticisation. Nonetheless it appears equally agreed that increasing roboticisation is highly likely and that the doll market itself has developed and needs consideration. I thank the anonymous reviewers for their comments on this point.

${ }^{3}$ Whilst the scope of this article is restricted to England and Wales, it is notable that the issue is arising worldwide (see Mullaley 2018; Geary 2016). Matthews $(2019,288)$ notes successful Australian convictions for possession and dissemination of a child sex doll, see $R v$ Miao [2016] NSWDC 181. The St John's Case to which Mullaley (2018) refers was due for hearing in December 2018; at the time of writing (January 2019) I could not find any report of judgment.

${ }^{4}$ Full report no longer available. Hard copy on file with author.

${ }^{5}$ The Customs and Excise Management Act 1979 ss50 and 170(b) provide alternative charges relating to items restricted under the CCA.

${ }^{6}$ Sentencing information from court reports on file with author.

${ }^{7}$ Existing commentary (eg Sharkey et al. 2016; Danaher 2017; Behrendt 2017) appears to be largely general/philosophical in scope and does not (Matthews 2019; Strikwerda 2016; and Chatterjee 2017 excepted) discuss legal frameworks or substantially engage with the legal body of work on child pornography. Whilst Strikwerda (2016) discusses parallels with virtual i.e. purely fantasy child pornography and feminist critiques of pornography as well as legal moralism and paternalism, she does not consider the domestic legal framework. Mention of child sex dolls is made in Lydia DelicadoMoratalla (2018) however the article is in Spanish which I am unable to translate.

${ }^{8}$ Commentators on child pornography widely acknowledge that terminology in the field is contested and problematic, in that 'pornography' in particular implies legitimacy and consensual production, and may fail to capture the abusive nature of some imagery involving real children, thus 'child abuse imagery' is preferred. 'Child pornography' does not appear in the domestic framework, and what terms do exist are inconsistent across statutes therefore no one legal definition suggests itself as a catch-all descriptor.

${ }^{9} \mathrm{I}$ thank my anonymous reviewers for their views on this point.

${ }^{10} \mathrm{https}$ ://en.oxforddictionaries.com/thesaurus/image https://en.oxforddictionaries.com/definition/image

${ }^{11}$ Holographic child pornography is initially explored by Gillespie (2011). On the state of holographic art generally see Carter, 2016; Kamping-Carder 2018; Sullivan 2018.

12 The imagery would also need to meet the threshold of indecency. The pseudo-photography clause would likely cover the emergence of deepfake imagery and data sent to a 3D printer but arguably not the resulting three-dimensional artefacts.

${ }^{13}$ My thanks to Professor Suzanne Ost for drawing this provision to my attention.

${ }^{14}$ Of the 'manual', non-photographic style methods envisaged here, I appreciate it is unlikely that casting or abstract sculpture based on a real child would be used, due to the expertise required and relative difficulty of the task, but such methods are discussed as it is necessary to consider the breadth of possible media. As pointed out to me by my anonymous reviewers, although commercially-manufactured items remove the effort, there are now pornographic sites in existence that are devoted to exactly such 'homemade' dolls. Discussion thus illustrates the dangers of casting restrictions too narrowly - as Gillespie $(2011,19)$ notes, it is misleading to assume all material is photographic.

${ }^{15}$ Danaher $(2017,73)$ suggests that criminalisation in theory should depend on the crossing of 'some minimal threshold of human-likeness' and considers that the degree of human likeness may be evaluated with reference to appearance, movement and intelligence, yet he also appreciates that this question is less than straightforward. My thoughts on where the threshold might lie in practice are developed below.

${ }^{16}$ Interestingly, an image of a sex doll or robot could fall under the CoJA. I thank Professor Ost for this observation.

${ }^{17} \mathrm{~S} 143$ enables the courts to make an order of forfeiture of property which has been used for the purpose of committing or facilitating the commission of any offence. Thus, 3D printers may be forfeit as well as dolls and robots.

${ }^{18}$ Conegate concerned the importation of adult sex dolls. Whilst the debate hinged on whether the dolls were obscene, my reading of the case is that they can be considered articles for the purposes of the OPA, which suggests that child versions would be also. Compare Smith and Hogan $(1999,735)$ who state that 'In Conegate... it was conceded that inflatable life-sized dolls, though obscene, were not "articles". It has been suggested that the concession was wrong because the dolls, having faces painted on them, were to be "looked at".'

${ }^{19}$ Publication under the OPA may be construed as publication to one other person ( $R v G S$ [2012] EWCA Crim 398). 
${ }^{20}$ Only an offence of possession would address this, and there would also be the question of whether such an offence would be desirable if no child was harmed, see discussion below.

${ }^{21}$ For discussion on the differences in definitions between the postal offences and the OPA see Smith and Hogan (1999). The offences apply to packets handled by any postal operator.

${ }^{22}$ As stated I have focused on core offences, but other offences that could be relevant arise from the broader 'industry' that would be engendered by doll/robot creation include aiding and abetting; the provision of code; and the advertising for sale of such items. I am unable to explore these owing to constraints of space. I thank my anonymous reviewers for raising these issues with me.

${ }^{23}$ On the similarities and differences between the OPA and CoJA see Antoniou (2013). The MoJ

Guidance notes state that the CoJA simply criminalises the possession of material that was already illegal to publish under the OPA, but Antoniou (2013) challenges this, noting that the criteria of disgust is distinct to that of depravity and corruption.

${ }^{24}$ Matthews (2019) notes that child sex dolls are prohibited in Australia and that the Australian Department of Immigration and Border protection publishes guidance on prohibited imports that specifically mentions dolls where they appear to be manufactured for a sexual purpose and appear to be a depiction of a child under 18, and that any accessories/instructions/descriptive material accompanying the doll will be taken into account when determining the apparent age.

${ }^{25}$ For Mill $(1998,13)$, the harm principle holds that 'the only purpose for which power can rightfully be exercised over any member of a civilised community, against his will, is to prevent harm to others.'

${ }^{26}$ Ost $(2009,126)$ uses Feinberg to explain interest as "“things in which one has a stake" and which are vital to an individual's wellbeing.' See further Feinberg (1984).

${ }^{27}$ In this respect, criminalisation would be justified regardless of whether or not the child was aware of exploitation. See further Ost (2016).

${ }^{28}$ Such items need not necessarily be commercially manufactured in that 3D printing-machines are now available for home purchase at increasingly high specification and lower costs.

${ }^{29}$ Deepfake refers to AI technology that is used to create highly realistic but false video content, such as pornographic scenes apparently involving celebrities, but in reality made by the combination of thousands of their photos to create 'new' authentic-looking images. I thank my anonymous reviewers for raising this point with me. See further Schwartz (2018).

${ }^{30}$ On flesh-based robots in the medical context see Molloy (2017).

${ }^{31}$ The relatives of the child may also be profoundly distressed by the creation of a facsimile, see further Ost (2010 fn104; 2016).

${ }^{32}$ For analogous judicial discussion of knowledge, harm and the violation of rights see $P v$ Cheshire West \& Cheshire Council; $P \& Q v$ Surrey County Council [2014] UKSC 19.

${ }^{33}$ See discussion in the context of child pornography in Gillespie $(2011,279-80)$.

${ }^{34}$ Strictly speaking, the POCA offence is not limited to real children either as it includes pseudo-imagery, but it will be recalled that the pseudo-photography offence was introduced to stop offenders avoiding liability due to the inability of prosecutors to distinguish between high quality artificial and real images: the thrust of the POCA offences address real child pornography or material that appears as such.

${ }^{35}$ I read Strikwerda's argument as focusing solely on child sex robots that are purely fantasy creations. I justify my own consideration of the use of real children in the production of child sex dolls and robots, in that given the prevalence of real children occurring in abuse imagery, it is an arguably probable if not highly likely development.

${ }^{36}$ Although the feminist anti-pornography and virtue ethics arguments that underpin this value system may be critiqued in that they do not facilitate alternative views of sexuality such as consensual BDSM and/or same-sex pornography, the issues of consent that arise in child pornography are very different (see further Chatterjee 2012).

${ }^{37}$ Strikwerda $(2016,145)$ doubts the paternalism claim in that there is no evidence that those who would use child sex robots would also be contact offenders, thus the claim remains speculative.

${ }^{38}$ McGlynn and Rackley (2017) discuss the harms that arise where women do not consent to the dissemination of private adult sexual images. In the context of child sex dolls and robots, any consent on the child's part could not be seen as valid and thus harm would still be established.

${ }^{39}$ This definition is problematic on a wider scale as it does not acknowledge that sex robots may be male, or of an indeterminate sex, plus the analogy to prostitution is open to critique. On sex work and women purchasing sex see further Kingston (2016).

${ }^{40}$ This is through the House of Representatives and is at the time of writing referred to the Committee on the Judiciary in the Senate, see https://www.congress.gov/bill/115th-congress/house-

bill/4655/text?format=txt . For critique see https://medium.com/prostasia-foundation/does-congress-caremore-about-dolls-than-real-children-6ebea2679f49.

${ }^{41}$ On the blurred lines between sex and technology 24 Devlin (2015). 
${ }^{42}$ I thank my anonymous reviewers for raising this point with me.

${ }^{43}$ Aside from adult toys that are simply on a smaller scale, examples could include dilators for those with medical conditions or who are recovering from surgery following gender reassignment. I thank my anonymous reviewers for raising the problem of where to draw the line.

$\underline{\text { References }}$

Al-Alosi, Hadeel. 2018. The Criminalisation of Fantasy Material: Law and Sexually Explicit Representations of Fictional Children. Routledge: Abingdon

Antoniou, Alex. 2013. Possession of prohibited images of children: three years on. Journal of Criminal Law: 337-353.

Behrendt, Mark. 2017. Reflections on moral challenges posed by a therapeutic childlike sexbot. In Love and sex with robots: Third international conference LSR 2017, eds. Adrian Cheok and David Levy, 93-116. Springer: Switzerland

Bodkin, Henry. 2016. Sex robots to storm into the British bedroom within ten years. http://www.telegraph.co.uk/news/2016/06/09/sex-robots-to-storm-into-the-britishbedroom-within-ten-years/

Briefreport. 2017. Pervert jailed after trying to take 'child' sex doll through East Midlands Airport.

https://www.briefreport.co.uk/news/pervert-jailed-after-trying-to-take-child-sex-dollthrough-east-midlands-airport-5102526.html Full report no longer available. Hard copy on file with author.

Campaign against Sex Robots. 2012. https://campaignagainstsexrobots.org/about/

Carter, Jamie. 2016. Forget 3D, holograms are coming to smartphones.

https://www.techradar.com/news/phone-and-communications/mobile-phones/forget-3dholograms-are-coming-to-smartphones-1322395

Chatterjee, Bela Bonita. 2017. Child sex dolls and robots: Exploring the legal challenges. http://theconversation.com/child-sex-dolls-and-robots-exploring-the-legalchallenges-81912 
Chatterjee, Bela Bonita. 2012. Pay v UK, the probation service and consensual BDSM. Sexualities 15(5-6):739-757

Cork, Tristan. 2018. Somerset man in court for importing a child sex doll. Bristol Post https://www.bristolpost.co.uk/news/bristol-news/somerset-man-court-importing-child1299610

Child, John and Ormerod, David. 2015. Smith and Hogan's essentials of criminal law. OUP: Oxford.

Dale, Alex. 2018. 3D printing with living cells could revolutionize tissue engineering. https://labiotech.eu/tissue-engineering-cells-3d/

Dahaher, John. 2017. Robotic Rape and Robotic Child Sexual Abuse: Should They be Criminalised? Criminal Law and Philosophy 11: 71-95.

Danaher, and McArthur, Neil, eds. 2016. Robot sex: Social and ethical implications. MIT Press: Cambridge Massachusetts

Day, Harvey. 2017. First sex-doll only brothel opens in Germany following success of Austrian outlet as bizarre trend spreads across Europe. http://www.dailymail.co.uk/news/article-4993528/First-sex-doll-brothel-opensGermany.html

Dean, John. 2016. Sex robots could stop paedophiles and predators becoming dangers to society, expert claims. http://www.mirror.co.uk/news/uk-news/sex-robots-could-stoppaedophiles-9121408

Delicado-Moratalla, Lydia. 2018. Las claves de la prostitución Nigeriana: Una geopoltíca feminista Oñati Socio-Legal Series. Available at SSRN: https://ssrn.com/abstract=3202331 
Devlin, Hannah. 2017. Grow your own: The race to create body parts in the lab. https://www.theguardian.com/science/2017/dec/05/create-body-parts-replacement-skinregenerative-medicine\#img-1

Devlin, Kate. 2015. In defence of sex machines: why trying to ban sex robots is wrong. http://theconversation.com/in-defence-of-sex-machines-why-trying-to-ban-sex-robotsis-wrong-47641

Devlin, Kate. 2018. Turned On. Bloomsbury Sigma: London.

du Cann, Gerard. 2018. Inside the sex robot factory that's shipping $£ 6,000$ 'Harmony’ dolls to randy punters just in time for Christmas.

https://www.thesun.co.uk/news/8019004/sex-robot-factory-shipping-6000-harmonydolls-christmas/

Feinberg, Joel. 1984. Harm to Others. OUP: Oxford.

Feinberg, Joel. 1985. Offense to Others. OUP: Oxford.

Geary, Belinda Grant. 2016. That these devices even exist is abhorrent. http://www.dailymail.co.uk/news/article-3501037/That-devices-exist-abhorrent$\underline{\text { Petition-seeks-ban-importation-depraved-child-like-sex-dolls-Australia.html }}$

Gillespie, Alisdair A. 2011. Child pornography: Law and policy.

Glasshouse/Routledge: London.

Gillespie, Alisdair A. 2018. Child pornography. Information and Communications Technology Law 27(1): 30-54

The Guardian Podcast. 2017. The race to build the world's first sex robot. https://www.theguardian.com/news/audio/2017/may/05/the-race-to-build-the-worldsfirst-sex-robot-podcast 
Guilbert, Kieran. 2018. Amazon pulls child sex dolls after criticism from UK watchdog. http://news.trust.org/item/20180412142851-0e3cf

Gutiu, Sinziana. 2016. The roboticization of consent. In Robot Law eds., Calo, Ryan, Froomkin, Michael A and Kerr, Ian. Edward Elgar: Cheltenham

Hillyard, Paddy et al. (2005) Criminal obsessions: Why harm matters more than crime. https://www.crimeandjustice.org.uk/publications/criminal-obsessions-why-harmmatters-more-crime-2nd-edition

Home Office. 2007. Consultation on the possession of non-photographic visual depictions of child sexual abuse.

http://webarchive.nationalarchives.gov.uk/20100408151328/http://www.homeoffice.go v.uk/documents/cons-2007-depiction-sex-abuse2835.pdf?view=Binary

Horton, Helena. 2015. By 2050 human-on-robot sex will be more common than humanon-human sex, says report. http://www.telegraph.co.uk/technology/news/11898241/By2050-human-on-robot-sex-will-be-more-common-than-human-on-human-sex-saysreport.html

IFL Science (n.d.) http://www.iflscience.com/health-and-medicine/lab-grown-skincould-aid-our-understanding-skin-disorders/

Kamping-Carder, Leigh. 2018. How holograms are helping medical training. https://www.wsj.com/articles/how-holograms-are-helping-medical-training$\underline{1530795601}$

Kingston, Sarah. 2016. Women who buy sexual services in the UK. http://www.research.lancs.ac.uk/portal/en/publications/-(93d3dceb-9c50-4ec0-8e78$\underline{17 \mathrm{~b} 73 \mathrm{c} 3634 \mathrm{ac}) \cdot \mathrm{html}}$

Lacey, Nicola and Wells, Celia. 1998. Reconstructing Criminal Law. $2^{\text {nd }}$ ed. Butterworths: London. 
Lancashire Police. 2018. https://www.lancashire.police.uk/news/2018/june/mansentenced-for-importation-of-child-sex-doll/

Levy, David. 2009. Love and Sex with Robots. Gerald Duckworth and Co Ltd: London.

Levy, David. 2012. The ethics of robot prostitutes. In Robot Ethics, eds., Lin, Patrick, Abney, Keith and Bekey George A., 222-231. MIT Press: Cambridge Massachusetts

Matthews, Ben. 2019. New international frontiers in child sexual abuse. Springer:

Switzerland

McCrum, Kirstie. 2016. Child sex dolls the size of girls aged three available to buy in the UK ... and they're completely legal. https://www.mirror.co.uk/news/worldnews/child-sex-dolls-size-girls-8243468

McGlynn, Claire and Rackley, Erika. 2017. Image-Based Sexual Abuse. Oxford Journal of Legal Studies 37 (3): 534-561.

Mill, J.S. 1989. On Liberty and Other Writings ed. Collini, Stefan. CUP: Cambridge.

Molloy, Mark. 2017. Robots covered in human flesh could soon be reality.

https://www.telegraph.co.uk/technology/2017/03/07/robots-covered-human-flesh-couldsoon-reality/

Morin, Roc. 2016. Can child dolls keep pedophiles from offending?

https://www.theatlantic.com/health/archive/2016/01/can-child-dolls-keep-pedophiles-

from-offending/423324/

Mullaley, Rose. 2018. St John's sex doll case to carry over into 2018

http://www.thetelegram.com/news/st-johns-sex-doll-case-to-carry-over-into-2018$\underline{157283 /}$

Nash, Charlie. 2017. Sex robot brothels gaining popularity in Europe' 
https://www.breitbart.com/tech/2017/07/31/worlds-first-sex-robot-brothel-talks-expand/

Nash, Charlie. 2018. First sex doll brothel in North America to open in Toronto.

https://www.breitbart.com/tech/2018/08/28/first-sex-doll-brothel-in-north-america-toopen-in-toronto/

Ost, Suzanne. 2009. Child Pornography and Sexual Grooming: Legal and Societal Responses. CUP: Cambridge.

Ost, Suzanne. 2010. Criminalising fabricated images of child pornography: a matter of harm or morality. Legal Studies 30 (2): 230-256

Ost, Suzanne. 2016. A new paradigm of reparation for victims of child pornography. Legal Studies 36(4): 613-638.

Palmer, Maija (2016). Prospect of sexual relationships with robots poses moral dilemmas. https://www.ft.com/content/de4fc762-f746-11e5-96db-fc683b5e52db

Pasha-Robinson, Lucy. 2018. Lab-grown meat could be on sale by end of 2018, says producer. https://www.independent.co.uk/news/science/clean-meat-lab-grownavailable-restaurants-2018-global-warming-greenhouse-emissions-a8236676.html

Rawlinson, Kevin. 2017. Child sex doll imports expose previously unknown offenders. https://www.theguardian.com/society/2017/jul/31/child-sex-doll-imports-exposepreviously-unknown-offenders

Richardson, Kathleen. 2015. The asymmetric 'relationship': Parallels between prostitution and the development of sex robots' Research/Position Paper SIGCAS Computer and Society 45 (3): 290-293 available at https://campaignagainstsexrobots.org/the-asymmetrical-relationship-parallels-betweenprostitution-and-the-development-of-sex-robots/ 
Richardson, Kathleen. Forthcoming 2019. Sex robots: The end of love. Polity Books: Cambridge.

Schwartz, Oscar. 2018. You thought fake news was bad? Deep fakes are where the truth goes to die. https://www.theguardian.com/technology/2018/nov/12/deep-fakes-fakenews-truth

Sharkey, Noel, van Wynsberghe, Aimee, Robbins, Scott and Hancock, Eleanor. 2016. Our sexual future with robots. Foundation for Responsible Robotics Consultation Report available at https://responsiblerobotics.org/2017/07/05/frr-report-our-sexualfuture-with-robots/

Smith, John. 1999. Smith and Hogan criminal law. $9^{\text {th }}$ ed. Butterworths: London

Sparrow, Robert. 2017. Robots, rape and representation. International Journal of Social Robotics 9 (4): 465-477

Strikwerda, Litska. 2016. Legal and moral implications of child sex robots. In Danaher, John and McArthur, Neil., eds. Robot sex. 133-151. MIT Press: Cambridge Massachusetts

Sullivan, Amy. 2018. Amy Winehouse hologram expected to 'tour' with a backing band. https://www.npr.org/2018/10/18/658384024/amy-winehouse-hologram-expectedto-tour-with-a-backing-band?t=1539955212992

Wakefield, Jane. 2017. Call for a ban on child sex robots. http://www.bbc.co.uk/news/technology-40428976 